\title{
ECOlogical FoOTPRint OF THE PRODUCTION OF RAPESEED
}

\author{
Vindis, P., StajnKo, D., LAKota, M. \& KelC, D.
}

Abstract: We researched the impact of different soil tillage of rapeseed production on the environment. Our main goal was to determine the ecological footprint in the comparison of three different types of tillage: conventional, conservational and direct sowing. The purpose of the research was to determine which method of rapeseed production is the most appropriate from environmental aspect. The experiment was carried out on an estate of Perutnina Ptuj d.d. in Podova. We determined that conventional tillage has a maximum footprint of 41.7 ha, followed by conversational tillage with 37.6 ha. Direct sowing with footprint of 36.6 ha brought the least burden on the environment. Small differences regarding ecological footprint were found when using the same amount of fertilizers and pesticides. We conclude that the conversational tillage is the most appropriate in rape production.

Key words: Ecological footprint, conventional tillage, conservation tillage, direct sowing
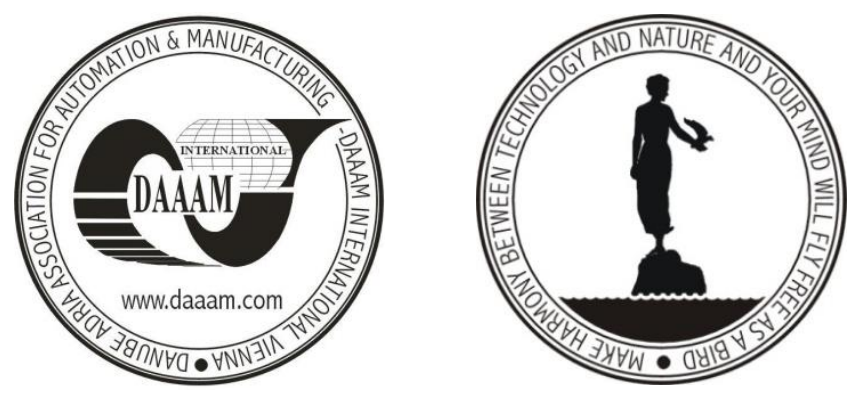

Authors' data: Assist. Prof. Dr. Vindis, P[eter]; Full. Prof. Stajnko, D[enis]; Assoc. Prof. Lakota, M[iran], Dr. Kelc, D[amijan], University of Maribor, Faculty of Agriculture and Life Sciences, Pivola 10, SI-2311, Hoce, Slovenia, peter.vindis@um.si,denis.stajnko@um.si,miran.lakota@um.si,damijan.kelc@um.si

This Publication has to be referred as: Vindis, P[eter]; Stajnko, D[enis]; Lakota, M[iran] \& Kelc, D[amijan] (2016). Ecological Footprint of the Production of Rapeseed, Chapter 20 in DAAAM International Scientific Book 2016, pp.217-224, B. Katalinic (Ed.), Published by DAAAM International, ISBN 978-3-902734-09-9, ISSN 1726-9687, Vienna, Austria

DOI: $10.2507 /$ daaam.scibook.2016.20 
Vindis, P.; Stajnko, D.; Lakota, M. \& Kelc, D.: Ecological Footprint of the Producti...

\section{Introduction}

Rapeseed (Brassica napus L. var. Napus) is the most important oleaginous plant from the family Brassicaceae. Industrial production of oil seed rape has started in the sixties of the $20^{\text {th }}$ century, when new varieties were introduced with little or no for human health and domestic animals harmful fatty acids in the oil, erucic and glucosinolates in the grain (Kocjan, 2015).

The main economic importance of rapeseed is that it produces a relatively high yield of grain having high oil content. Grain yield is normally 2 to 3.5 tonnes per hectare in extremely favourable conditions even more than 5 tonnes per hectare. Since the grain contains 42 to $45 \%$ of oil, the yield of oil per hectare is about 1100 or even up to $1350 \mathrm{~kg}$. The value of rapeseed is not only assessing with the quantity of produced seed and oil, but even more with the quality of these oils (Tajnšek, 1987).

\subsection{Ecological footprint}

Wackernagel and Rees developed ecological footprint in year 1996. It presupposes that every individual, process, activity and area has impact on the planet through the use of natural resources, waste and use of natural processes. These impacts can be converted into biologically productive land (such as land upon which the photosynthesis and biomass is produced). The Ecological Footprint is determined by comparing bio capacity of uncultivated land with the impact of man on nature. Bio capacity is representing biologically active areas, such as forests, pastures, fields and water surfaces. Maximum bio capacity has surfaces that leave them untreated because these increase their positive impact. These surfaces can absorb a large amount of waste and significantly reduce carbon dioxide emissions. Bio capacity is then compared with the impact of humankind on nature (Global Footprint Network, 2016; Berk et al., 2016).

\subsection{Different soil tillage techniques}

Over the years methods of soil tillage varied as they are encountered more and more new tillage technologies that are at the same time increasing the cost of fuel and labour. With the adoption of less intensive cultivation methods, many farmers realize the negative effects of conventional tillage and see the benefits of maintaining residues on the soil surface. Systems of production without tillage left on the land surface maximum of residues and often prove to be the most profitable method of production (CropWatch, 2016; Rakun et al, 2015).

There are three different tillage methods: conventional tillage, conservation tillage and direct sowing without any tillage. For conventional tillage the soil is annual plough. Plough turns the furrow, loosens the soil of treated layer, completely cover the crop residues, manure and weeds. Followed by pre-sowing tillage, which levelled the surface, crush lumps, if necessary, thicken the layer of soil. Followed by sowing after the harvest but stubble processing.

Conservation tillage is soil method tillage which left on the surface the plant residues of previous crop (such as corn stalks or wheat straw), before and after the sowing of the next crop, in order to reduce soil erosion. For this purpose, it must 
remain covered with the remains before sowing at least $30 \%$ of the surface soil. Some conservation tillage methods renounce traditional tillage and leave seventy percent and even more crop residues on surface. Conservation tillage is especially suitable for the soil tillage where soil is exposed to erosion.

In direct sowing we directly sow into uncultivated soil. Direct sowing is a measure against erosion on sloping lands and measures to prevent leaching of nitrate in lowland areas. The plant residues on the surface serve to protect against evaporation of moisture from the soil and increase the biological activity and the formation of humus (Klemenčič, 1998).

\section{Methods and materials}

\subsection{Location of the experiment}

The experiment was carried out in years 2013 and 2014 in location named Podova. Location of the experiment is shown in Figure 1. Coordinates of the field are $46^{\circ} 25^{\prime} 52^{\prime \prime} \mathrm{N}$ and $15^{\circ} 42^{\prime} 47^{\prime \prime} \mathrm{E}$. The local name of the arable land is Podova. The total area of arable land is 10.7 hectares and average altitude of 250 meters. The plot was divided into three equal parts. Soils are sandy brown or light district.

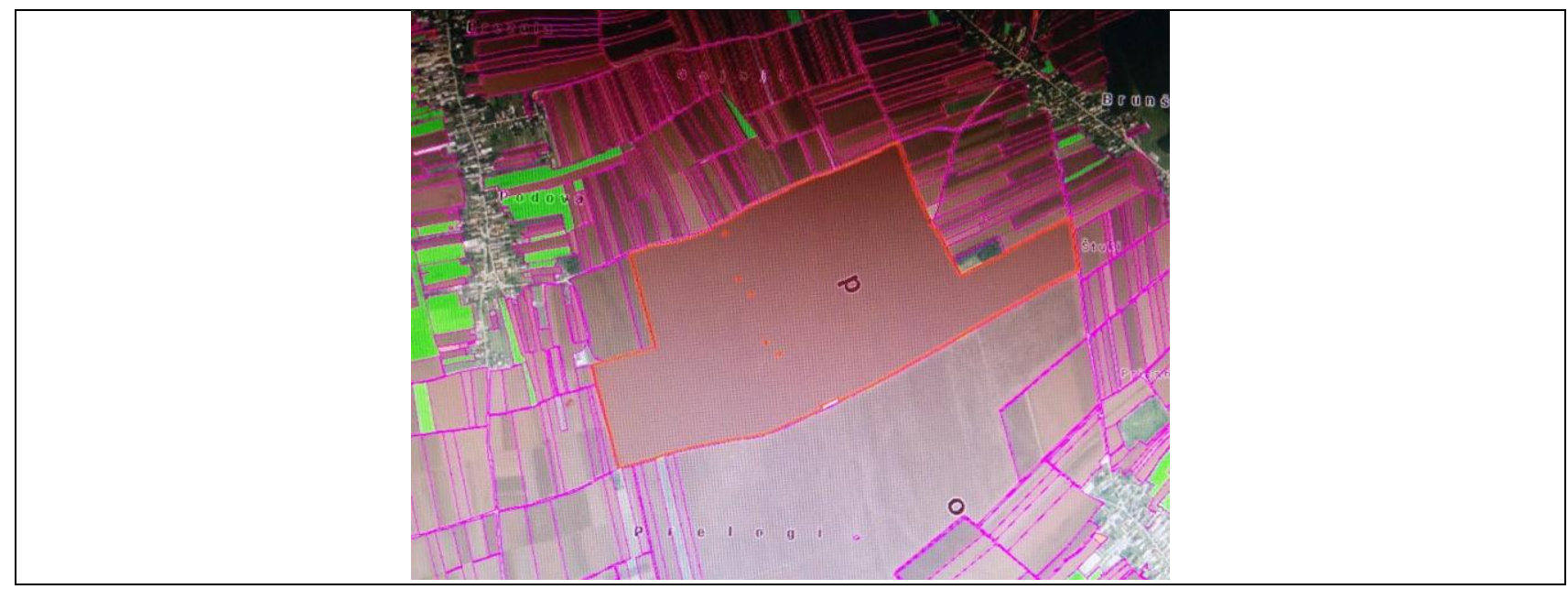

Fig. 1. Location of the experiment

In our experiment, we used hybrid of rapeseed PR46W26. Hybrid PR46W26 has a high yield of grain and a high content of oil in it. PR46W26 is a medium early hybrid, good winter hardy and has good resistance to lodging. With a high yield and a high content of oil it is very profitable. We must also consider that it is susceptible to pests and diseases. In year 2013 it was one of the highest-yielding hybrids (LELF, 2015).

\subsection{SPIonWeb online program for calculating the ecological footprint}

For the calculation of the ecological footprint was used SPIonWeb program, developed by Krotscheck and Narodoslawsky. SPIonWeb is a free program that calculates the ecological impact of technical processes on the environment throughout the life cycle, including raw materials and with all emissions and wastes. SPIonWeb calculates the ecological footprint with the Sustainable Process Index 
Vindis, P.; Stajnko, D.; Lakota, M. \& Kelc, D.: Ecological Footprint of the Producti... (SPI) method, including carbon dioxide emissions and global warming potential (GWP).

\subsection{Machinery used in the experiment}

Table 1 show the machinery which was used in the experiment with the most important specifications.

\begin{tabular}{|c|c|c|c|c|}
\hline TASK & TRACTOR & MACHINE & $\begin{array}{c}\text { LABOUR } \\
\text { PRODUCTIVITY } \\
(\text { ha/h) }\end{array}$ & $\begin{array}{c}\text { FUEL CONSUMTION } \\
(\mathbf{l} / \mathbf{h})\end{array}$ \\
\hline \multicolumn{5}{|c|}{ Conventional tillage } \\
\hline Basic tillage & Fendt 818 & Plough Regent 4B & 0,5 & 13 \\
\hline $\begin{array}{l}\text { Before sowing } \\
\text { tillage }\end{array}$ & Fendt 818 & $\begin{array}{l}\text { Harrow Kverneland } \\
4 \mathrm{~m}\end{array}$ & 10 & 11 \\
\hline \multicolumn{5}{|c|}{ Conservation tillage } \\
\hline Basic tillage & $\begin{array}{c}\text { Challenger MT } \\
875 \mathrm{~B}\end{array}$ & $\begin{array}{l}\text { Väderstad Top Down } \\
6 \mathrm{~m}\end{array}$ & 5 & 57 \\
\hline \multicolumn{5}{|c|}{ All tillage's } \\
\hline Spraying & Fendt 309 & RAU $24 \mathrm{~m}$ & 14 & 7 \\
\hline Fertilizing & Fendt 309 & $\begin{array}{c}\text { Amazone ZA-M } 24 \\
\mathrm{~m}\end{array}$ & 14 & 7 \\
\hline Seeding & Fendt 930 & Amazone & 5 & 20 \\
\hline
\end{tabular}

Tab. 1. Machinery, their use and productivity of the various soil tillage methods.

In the conventional tillage was for ploughing and beffore sowing tillage used tractor Fendt 818. The engine of the tractor has 6.1 -liters of volume, $138 \mathrm{~kW}$ of power and $803 \mathrm{Nm}$ of torque at $1450 \mathrm{rpm}$. The tractor has installed a continuously variable hydromechanical transmission. For spraying and fertilizing was used tractor Fendt 309. The engine of the tractor has a 4.2 liter of capacity, $70.8 \mathrm{~kW}$ of power and $375 \mathrm{Nm}$ of torque at $1500 \mathrm{rpm}$ of engine. In conventional tillage was used for basic tillage four harrow reversible plough Regent (figure 2, left) and rotary harrow Kverneland with working width of $4 \mathrm{~m}$ (figure 2, right).
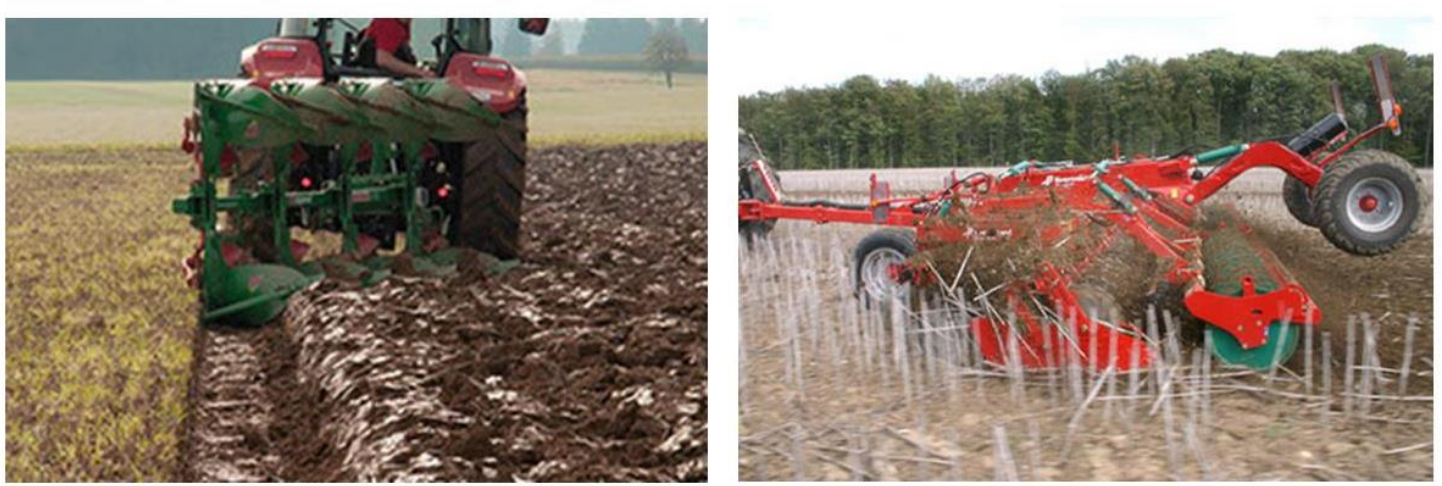

Fig. 2. Plough Regent on the left and harrow Kverneland on the right 
For conservation tillage we used tractor Challenger MT875B (figure 3, left). The tractor engine has a 18.1-liters of capacity and develops $570 \mathrm{hp}$ at $2100 \mathrm{rpm}$ of engine. For conservation tillage we used the Väderstadt Top Down 600. The machine has a working width of 5.75 meters, transport width of 3 meters, pumping height 3.6 meters and weight $9100 \mathrm{~kg}$. Recommended operating speed is between 8 and $12 \mathrm{~km} /$ h.

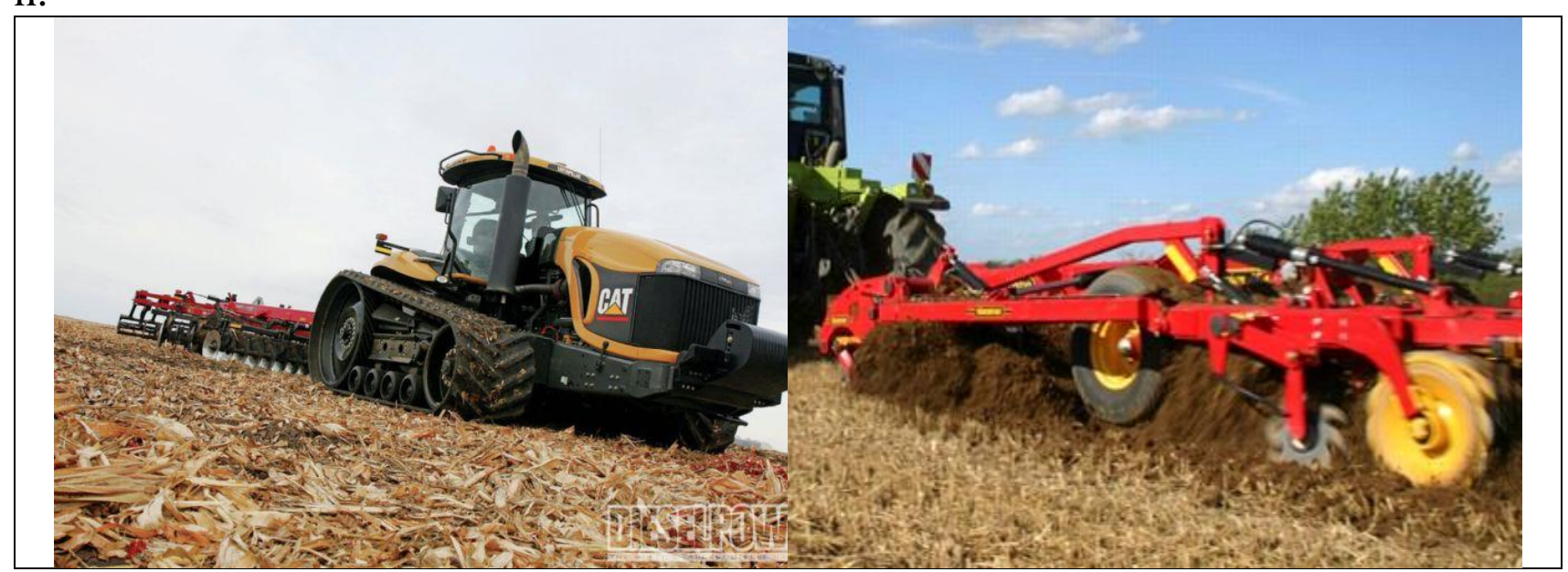

Fig. 3. Challenger MT875B (left) and Väderstadt Top Down 600 (right)

In the experiment, we always use a sowing combination Amazone and sprayed with a sprayer RAU.

\subsection{Production technology of rapeseed}

Table 2 shows the production technoloy of rapeseed.

\begin{tabular}{|c|c|c|c|}
\hline FERTILIZING & $\begin{array}{c}\text { THE AMOUNT OF } \\
\text { FERTILIZER }(\mathrm{kg} / \mathrm{ha})\end{array}$ & SPRAYING & $\begin{array}{l}\text { THE AMOUNT OF } \\
\text { PESTICIDES (1/ha) }\end{array}$ \\
\hline $\begin{array}{c}\text { Basic: } \\
\text { NPK 6:12:24 }\end{array}$ & 400 & $\begin{array}{c}\text { 1. spraying } \\
\text { fungicide Folicur } \\
\text { insecticide Chess }\end{array}$ & $\begin{array}{l}0,7 \\
0,3\end{array}$ \\
\hline $\begin{array}{l}\text { 1. fertilizing: } \\
\text { KAN } 27 \%\end{array}$ & 280 & $\begin{array}{l}\text { 2. spraying } \\
\text { fungicide Folicur } \\
\text { insecticide Chess }\end{array}$ & $\begin{array}{c}0,7 \\
150(\mathrm{~g} / \mathrm{ha})\end{array}$ \\
\hline $\begin{array}{l}\text { 2. fertilizing: } \\
\text { N-GOO } 32 \%\end{array}$ & 250 & & \\
\hline $\begin{array}{c}\text { Foliar application: } \\
\text { FOLIBOR }\end{array}$ & $2(1 / \mathrm{ha})$ & & \\
\hline $\begin{array}{c}\text { Foliar application: } \\
\text { LABI FITO }\end{array}$ & $2(1 / \mathrm{ha})$ & & \\
\hline
\end{tabular}

Tab. 2. Production technology of rapeseed.

\section{Results}

Table 3 shows yield of the production of rapeseed for each type of soil tillage separately. Conservation tillage gives the maximum yield of $3856 \mathrm{~kg}$ of rapeseed. $16 \%$ lower yield was obtained from the conventional tillage and the lowest yield was 
Vindis, P.; Stajnko, D.; Lakota, M. \& Kelc, D.: Ecological Footprint of the Producti... obtained in direct sowing (29\% less than conservation tillage and $15 \%$ less than conventional tillage).

\begin{tabular}{|cc|}
\hline TILLAGE METHODS & $\begin{array}{c}\text { YIELD OF RAPESEED } \\
(\mathrm{kg} / \mathrm{ha})\end{array}$ \\
\hline Conventional tillage & 3245 \\
\hline Conservation tillage & 3856 \\
\hline Direct sowing & 2745 \\
\hline
\end{tabular}

Tab. 3. Yield of rapeseed.

\subsection{Conventional tillage in the cultivation of rapeseed}

Figure 4 shows the results of soil tillage with the conventional tillage method. The largest ecological footprint has the use of nitrogen fertilizers with 22.3 ha $(53.5 \%$ of total footprint). Followed by the impact of the use of insecticide Cypermetrina, which amounted to 5.8 ha (13.8\% of total footprint), harvesting with a harvester in the size of 10 ha (11.7\% of total footprint), the use of phosphorus fertilizers with a value of 4 ha (9.5\% of total footprint) and the use of potassium fertilizer, which has left a footprint of 2.4 ha (5.7\% of total footprint). Other factors have a footprint of $5.8 \%$ of total footprint.

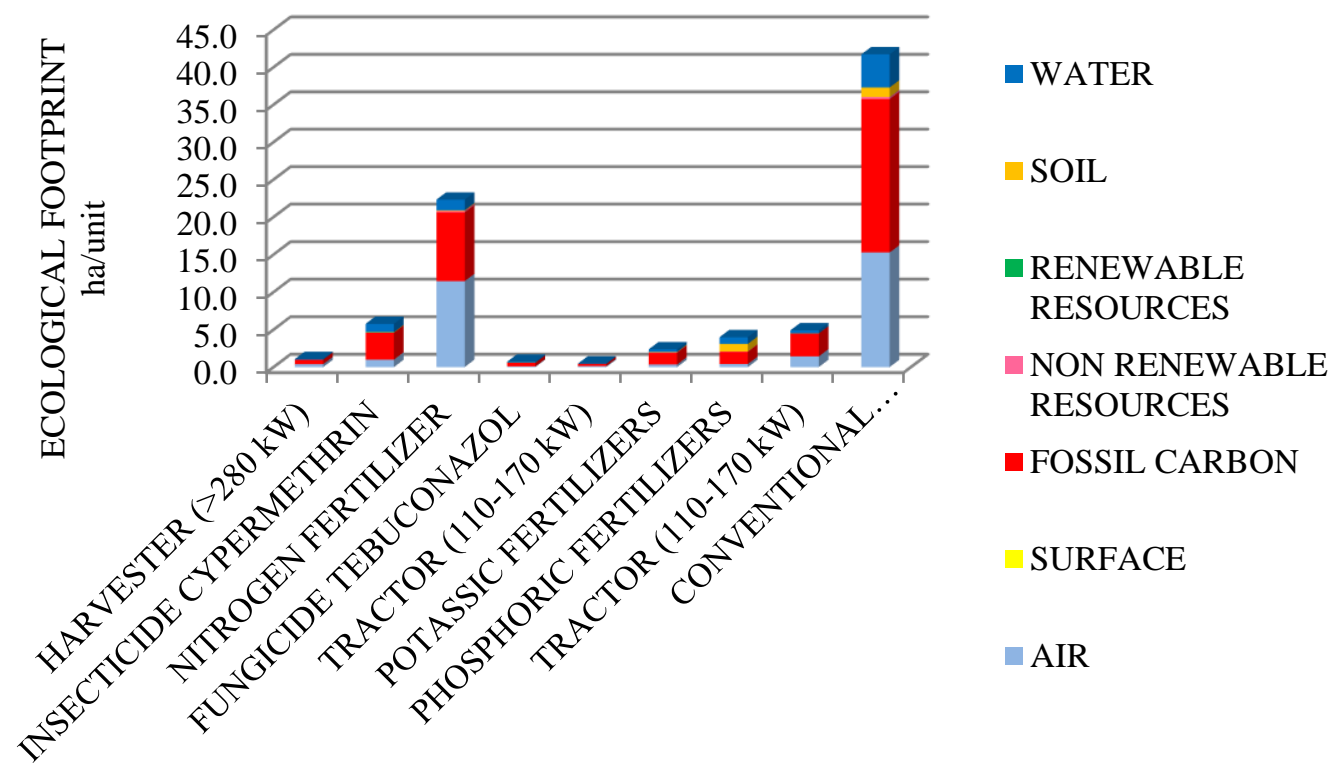

Fig.4. The ecological footprint of conventional rapeseed production

\subsection{Conservation tillage in the cultivation of rapeseed}

Figure 5 shows the results of soil tillage with the conservational tillage method. The use of nitrogen fertilizers has the largest ecological footprint up to 22.3 ha (59.3\% of total footprint). Followed by the ecological footprint in the application of the insecticide Cypermethrin, which amounted to 5.8 ha (15.3\% of total footprint), then the use of phosphorous fertilizers with the footprint of 4 ha $(10.6 \%$ of total footprint) and the use of potash fertilizers with the footprint of 2.4 ha $(6.3 \%$ of total 
footprint). Using the harvester has the footprint of 1.1 ha (2.8\% of total footprint), other factors had a $5.8 \%$ impact.

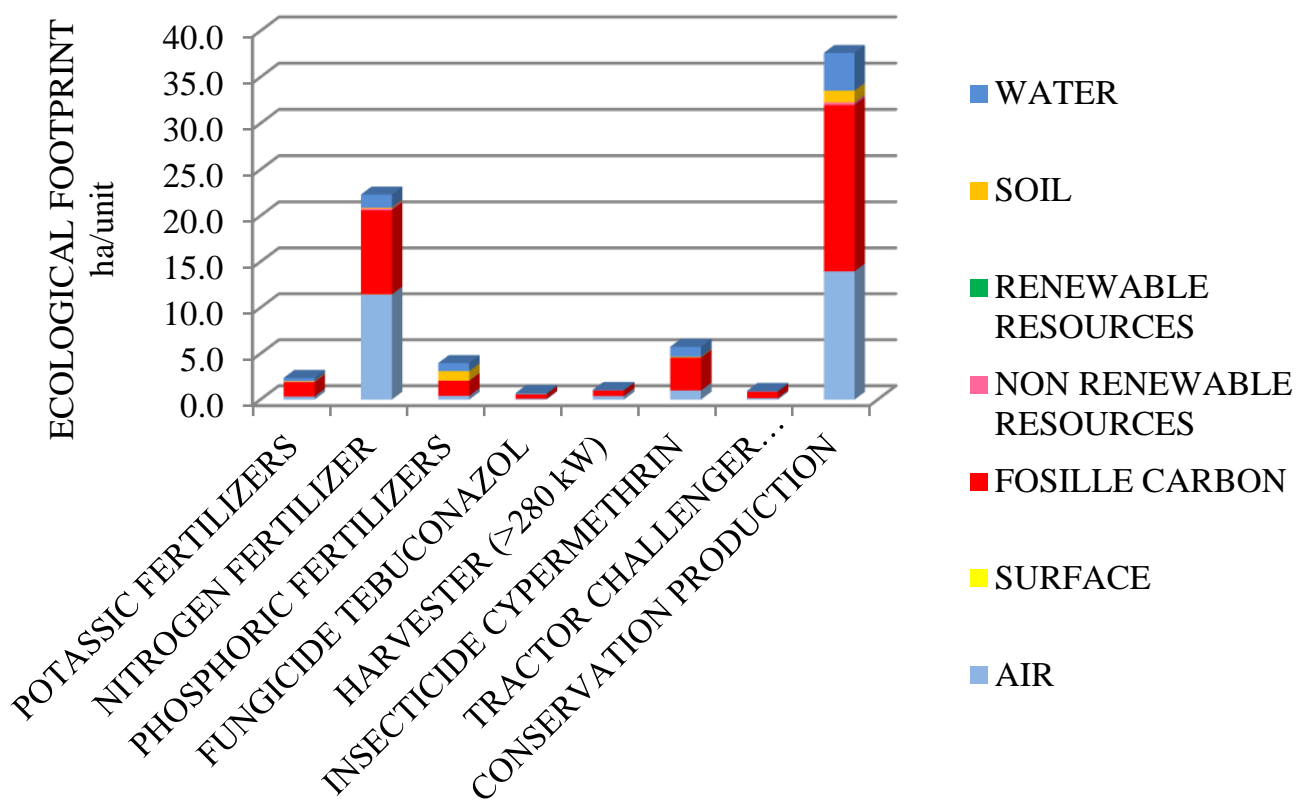

Fig.5. The ecological footprint of conservation rapeseed production

\subsection{Direct sowing}

Figure 6 shows the effects of various factors on footprint in direct sowing.

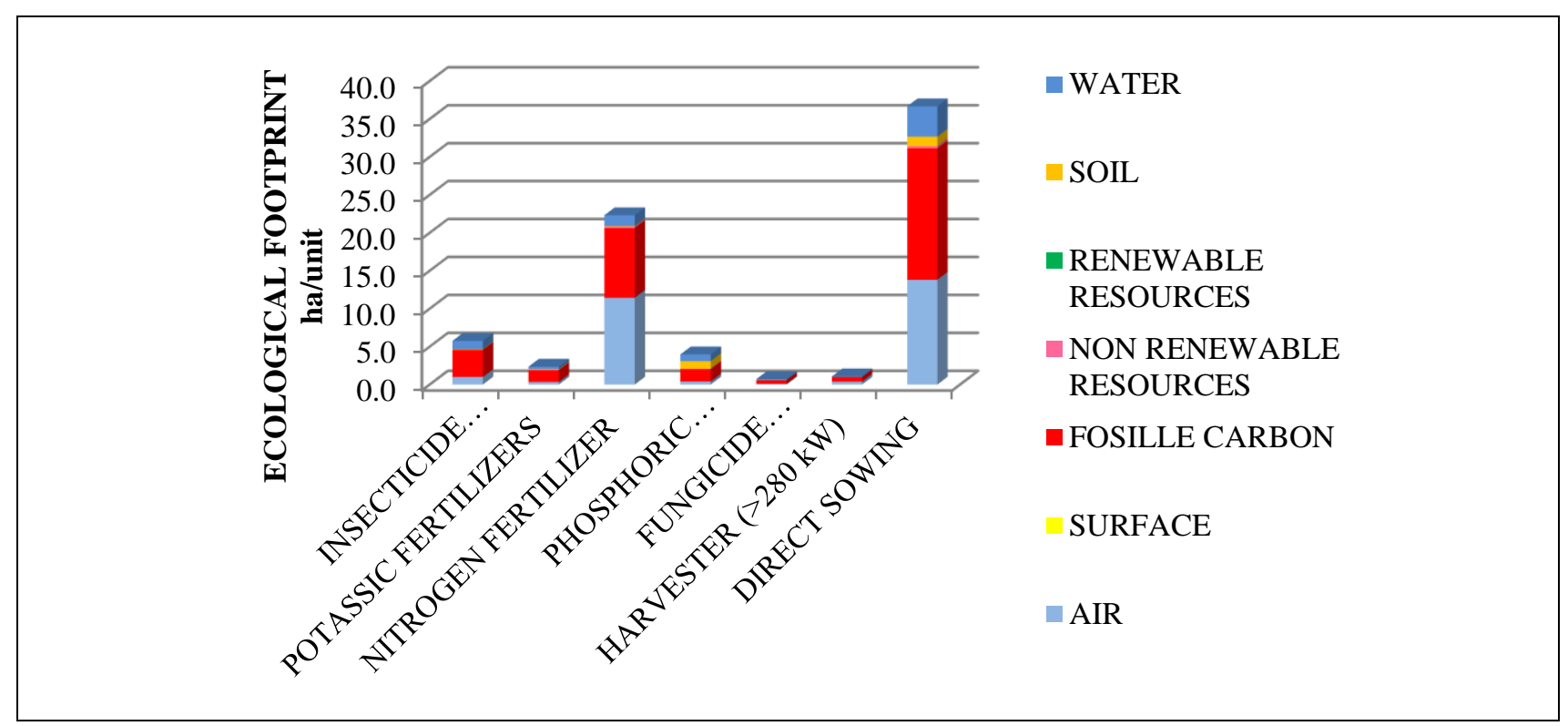

Fig.6. The ecological footprint of direct sowing rapeseed production

The largest ecological footprint of 22.3 ha ( $60.8 \%$ of total footprint) has the use of nitrogen fertilizers, followed by the use of the insecticide Cypermethrin with the ecological footprint of 5.8 hectares $(15.7 \%$ of total footprint), then the use of phosphorous fertilizers with a footprint of 4 ha (10.8\% of total footprint) and the use of potash fertilizers with the ecological footprint of 2.4 hectares $(6.4 \%$ of total 
Vindis, P.; Stajnko, D.; Lakota, M. \& Kelc, D.: Ecological Footprint of the Producti...

footprint). Using the harvester has a footprint of 1.1 hectares or $2.9 \%$ of total footprint, other factors had a $3.3 \%$ of impact.

\section{Conclusion}

In this study we evaluated the impacts of different ways of tillage of rape on the environment. We calculated the ecological footprint with web application SPIonWeb. We compared conventional tillage, conservation tillage and direct sowing without any tillage.

With the experiment we found that for the practice the most suitable is conservation tillage in rapeseed production, because it causes the smallest ecological footprint per unit of product and has the smallest impact on the environment. We must be aware that the information was obtained on the field, where 8 years conservation tillage was used. On the other filed the results could be different. There were small differences between footprint between different soil tillage's. This is due using the same amount of fertilizers and pesticides.

Future plans will focus on calculating the ecological footprint on others most common crops in our fields (maize, winter wheat, winter barley, oil pumpkins,...).

\section{References}

Berk, P.; Hočevar,; M. Stajnko, D. \& Belšak, Aleš (2016). Development of alternative plant protection product application techniques in orchards, Based on measurement sensing systems: a review, Computers and electronics in agriculture, vol. 124, pp. 273-288

CropWatch. http://cropwatch.unl.edu/tillage Accesed on: 2016-06-10

Global Footprint Network.

http://www.footprintnetwork.org/en/index.php/GFN/page/footprint_basics_overview/ Accesed on: 2016-05-18

Klemenčič, S. \& Rihtarič, D. (1998). How to properly plough. Agricultural Institute Maribor, Maribor, 34 str.

Kocjan, AD. (2015). Crops cultivation and use. Farmer voice, ISBN 978-961-203429-0, Ljubljana, 187 str.

LELF, Landesamt für Ländliche Entwicklung, Landwirtschaft und Flurneuordnung. http://www.isip.de/isip/servlet/contentblob/55360/Dokument/43673 Accesed on: 2016-06-18

Rakun, J.; Berk, P. \& Lakota, M. (2015). Fruit sorting based on texture analysis and support vector machine classification. V: KATALINIĆ, Branko (ur.). DAAAM International scientific book, DAAAM International scientific book, ISSN 17269687). Viena, pp.. 209-218

Tajnšek, T. (1987). Rapeseed and sunflower. Farmer voice, ISBN 978-961-203-4290, Ljubljana, 104 str. 